\title{
Sodium/Potassium/Calcium Exchanger 4
}

National Cancer Institute

\section{Source}

National Cancer Institute. Sodium/Potassium/Calcium Exchanger 4. NCI Thesaurus.

Code C162364.

Sodium/potassium/calcium exchanger 4 ( $622 \mathrm{aa}, \sim 69 \mathrm{kDa}$ ) is encoded by the human

SLC24A4 gene. This protein is involved in sodium ion-dependent calcium and potassium transport. 